\title{
Researcher Teacher Program: Achievements and Shortcomings
}

\author{
Shamsi Nami ${ }^{1} \&$ Nematallah Matin ${ }^{1}$ \\ ${ }^{1}$ Faculty member of Organization for Educational Research and Planning (OERP), Iran \\ Correspondence: Shamsi Nami, Faculty member of Organization for Educational Research and Planning (OERP), \\ Iran. E-mail: shamsinami@gmail.com
}

Received: July 24, 2016

doi:10.5539/ies.v10n3p99
Accepted: October 10, $2016 \quad$ Online Published: February 27, 2017

URL: https://doi.org/10.5539/ies.v10n3p99

\begin{abstract}
This paper reports the results of a study entitled "Pathology and Researcher Teacher Program promotion and development approaches". The aim of this study is to identify achievements, the cooperation and participation of teachers and principals in school activities in Researcher Teacher Plan and awareness of the shortcomings and obstacles in the implementation of this program. The research method is descriptive. The population statistic in this study involves two groups of researcher and non-researcher teachers and administrators. The sample consisted of 500 members who are estimated according to the population size on the basis of Kerjcie and Morgan table. Moreover, to select desired sample, multi-stage sampling method is used. Totally, 19 districts region of Tehran are divided into 5 categories and one region is randomly selected of each category and also from each region girls and boy's school in primary school, secondary and high schools are chosen randomly and a number of researcher and non-researcher teachers and administrators of schools are selected randomly as samples size. Two types of questionnaire are used for data collection. In order to study the form and content tools, the opinions of 10 experts and Cronbach's alpha is used to calculate reliability. The results showed that obstacles and shortcomings measurement has are significant level of $\mathrm{P}<0.5$ and alpha coefficient is obtained 0.715 and questionnaire to assess the qualitative achievements of the plan has a significant level $\mathrm{P}<0.5$ and Alpha as 0.587 . Results showed achievements for researcher teacher is far greater than non- researcher teachers and administrators. Furthermore, researcher teachers and administrators have participated more than non-researcher ones in holding briefings, workshops and council meetings teachers but no significant differences appears in participation between the two groups of teachers in workshops and council meetings there. Non-Researcher teachers and administrators state that obstacles and shortcomings of non-researcher teacher's plans are more than researcher teachers and administrators. However, both group almost are deployed similarly the first six obstacles as priorities 1 to 6 .
\end{abstract}

Keywords: teachers, administrators, researcher teacher program, Iranian education

\section{Introduction}

Researcher Teacher Program is type of program that started in 1375 by the Institute for education and its implementation has continued annually (Haqgoo, 2004). In current year 18th meetings of researcher teacher has been implemented. The aim of this program is to enforce teachers to undertake research during identifying the education problems and improving the quality of education. Although teachers participations in this program has so far upward trend and this has led to the continued existence of the program but this program also faced difficulties despite sufficient achievements (Qasemi-Puya, 2003, Moghaddam, 2014, Esfahani, 2016). Identification of these problems and removing obstacles in the way can lead to the development of this plan.

\section{Problem Statement}

Action research approach has penetrated in the field of educational research by the social movement known as the "researcher teacher" during (1960-1970). Action research is a kind of Practitioner research is executed during job schedule and can help teachers do a better manner in their job duties. Levin consider teacher as the most worthy person in recognition of the problem and finding a solution in the process of action research (Ahanchian, 2007, Moghaddam, 2016).

The movement of researcher teacher is commenced by with Lawrence Austin House (1975-1971). According to his viewpoint, whole training should be established based on research and study and improve curriculum is the duty of teachers (Chaychi, 2005, Moghaddam, 2015). Based on international experiences in this field, researcher 
teacher program is designed and implemented in Iran. The objectives of this program include honoring the experiences of research and teachers innovation in classroom, creating incentives for the growth and development of teachers, self-esteem and contributing growth of potential talents of educational teachers and managers and employees to solve problems, provide grounds for rehabilitation and effectiveness in the process of education in the country and also involvement of teachers in research projects handling and documentation of their experiences (Institute of Education, Tehran, 1996).

Currently, this program is underway for the nineteenth time. Continued existence of this program indicates its efficiency and effectiveness. However, research studied in this area shows that despite demonstrating appropriate results, this program has encountered difficulties (Nami, 2014; Amoozaadeh, 2005; Chaychi, 2006). This research seeks to fine damages and defects of researcher teacher program and achieve development strategies from the perspective of researcher and non- researcher teachers and administrators. The researcher teachers and administrators are people who have participated in the Tehran researcher teacher program at least once time and besides non-researcher teachers and administrators are ones who have never participated in this program.

Questions of the research study

1) Are there significant difference between two groups of researcher and non-researcher teachers and administrators about achievements of the programs?

2) Is there a significant difference between participation rates of two groups of researcher and non-researcher teachers and administrators in school activities in the context of the program?

3) Is there a significant difference between two groups of researcher and non-researcher teachers and administrators about the shortcomings and obstacles of the program?

\section{Research Method}

The research method of this study is descriptive (survey). The population of this research has focused on two groups: the first group includes researcher teachers and administrators (at least have participated once time in researcher teacher program in Tehran) and second group encompass non-researcher teachers and administrators (which is never participated in researcher teacher program).

The sample size consisted of 500 researcher and non-researcher teachers and administrators who are estimated according to population size on the basis of Kerjcie and Morgan table. To select a desired sample, multi-stage sampling method is used. The 19 districts region of Tehran are divided into 5 classes on the basis of cultural, social and economic and then one region from each category (totally 5 regions) has been selected randomly.

Two types of questionnaire are used for data collection. In order to study the form and content tools, the opinions of 10 experts and Cronbach's alpha is used to calculate reliability. The results showed that obstacles and shortcomings measurement has are significant level of $\mathrm{P}<0.5$ and alpha coefficient is obtained 0.715 and questionnaire to assess the qualitative achievements of the plan has a significant level $\mathrm{P}<0.5$ and Alpha as 0.587 .

\section{Research Results}

Demographic information about those who have attempted to complete and return the questionnaire indicated that $39.3 \%$ of them were managers and assistants of schools and $60.7 \%$ of them were teachers. About 56 percent of respondents are employed in boy's schools and about 44 percent are employed in girls' schools in Tehran. About $65 \%$ of the population statistic owned bachelor's degree and about 15 percent of them were owned master's degree and 20 percent have not mentioned their educations. Moreover, about 47.4 percent of respondents were teaching in elementary school, 20.42 in middle school and $32.4 \%$ in secondary school. Finally, about 58.9 percent of teachers has passed training course of action research.

In this section, research questions are answered using the findings of the research.

Answer to the first question) Are there significant difference between two groups of researcher and non-researcher teachers and administrators about achievements of the programs?

In order to answer this research question, 19 questions are included in the questionnaire. These questions seek to evaluate the effectiveness of researcher teacher program on knowledge enhancement, attitudes improvement and behaviors of teachers and school managers and transforming research-oriented atmosphere and space. In above Table, mean scores of both group's responses and their ranking are listed in addition of number of respondents. 
Table 1. Qualitative achievements of researcher teacher program

\begin{tabular}{|c|c|c|c|c|c|c|c|}
\hline \multicolumn{3}{|c|}{$\begin{array}{l}\text { Non researcher teachers and } \\
\text { principals } \\
\end{array}$} & \multicolumn{3}{|c|}{$\begin{array}{l}\text { Researcher Teachers and } \\
\text { administrators }\end{array}$} & \multirow[b]{2}{*}{ Achievements of researcher teacher } & \multirow[b]{2}{*}{ row } \\
\hline rank & $\begin{array}{l}\text { Average } \\
\text { on a } \\
\text { scale } 1-5\end{array}$ & number & rank & $\begin{array}{l}\text { Average } \\
\text { on a } \\
\text { scale } 1-5\end{array}$ & number & & \\
\hline 2 & 3.86 & 195 & 5 & 3.92 & 215 & $\begin{array}{l}\text { Researcher Teacher program is to increase teachers' } \\
\text { competence in solving problems in the classroom. }\end{array}$ & 1 \\
\hline 1 & 3.38 & 197 & 3 & 3.97 & 216 & $\begin{array}{l}\text { Researcher Teacher program has been enhanced } \\
\text { self-esteem among teachers. }\end{array}$ & 2 \\
\hline 13 & 3.24 & 193 & 12 & 3.79 & 215 & $\begin{array}{l}\text { Researcher Teacher program creates opportunities for all } \\
\text { teachers in different disciplines to exploit research. }\end{array}$ & 3 \\
\hline 5 & 3.33 & 194 & 1 & 4.00 & 214 & $\begin{array}{l}\text { Researcher Teacher program can develop innovation in } \\
\text { curriculum and solve student behavioral and educational } \\
\text { problems. }\end{array}$ & 4 \\
\hline 14 & 3.24 & 195 & 9 & 3.81 & 213 & $\begin{array}{l}\text { Researcher Teacher's increase the necessity of this } \\
\text { research on resolving education issues }\end{array}$ & 5 \\
\hline 19 & 3.09 & 194 & 18 & 3.57 & 216 & $\begin{array}{l}\text { Researcher Teacher's spread a relative concept and } \\
\text { philosophy of researcher teacher among teachers. }\end{array}$ & 6 \\
\hline 7 & 3.30 & 195 & 6 & 3.89 & 215 & $\begin{array}{l}\text { Researcher Teacher's may growth potential and talents of } \\
\text { teacher. }\end{array}$ & 7 \\
\hline 12 & 3.24 & 189 & 7 & 3.84 & 212 & $\begin{array}{l}\text { Researcher Teacher program change the attitudes of the } \\
\text { teachers towards research. }\end{array}$ & 8 \\
\hline 4 & 3.33 & 190 & 4 & 3.97 & 216 & $\begin{array}{l}\text { Researcher Teacher program may cause mental } \\
\text { involvement of teachers with scientific approach in the } \\
\text { teaching-learning process. }\end{array}$ & 9 \\
\hline 3 & 3.35 & 188 & 13 & 3.78 & 210 & $\begin{array}{l}\text { Researcher Teacher program change the attitudes of the } \\
\text { administrators toward the research. }\end{array}$ & 10 \\
\hline 11 & 3.25 & 194 & 14 & 3.76 & 215 & $\begin{array}{c}\text { Researcher Teacher program creates opportunities for } \\
\text { interaction and collaboration between teachers, } \\
\text { administrators and students. }\end{array}$ & 11 \\
\hline 6 & 3.32 & 192 & 2 & 3.99 & 214 & $\begin{array}{l}\text { Researcher Teacher program makes teachers' academic } \\
\text { experiences as a document. }\end{array}$ & 12 \\
\hline 17 & 3.14 & 189 & 15 & 3.76 & 212 & $\begin{array}{l}\text { Researcher Teacher program leading to magnify } \\
\text { professional roles of teacher. }\end{array}$ & 13 \\
\hline 18 & 3.10 & 193 & 19 & 3.47 & 214 & $\begin{array}{l}\text { Researcher Teacher program would provide the necessary } \\
\text { resources (books, periodicals, etc.) for research activities } \\
\text { of teachers. }\end{array}$ & 14 \\
\hline 8 & 3.30 & 193 & 10 & 3.81 & 216 & $\begin{array}{l}\text { Generally, this program would provide grounds for } \\
\text { enhancement of researcher teacher knowledge. }\end{array}$ & 15 \\
\hline 9 & 3.30 & 191 & 11 & 3.79 & 214 & $\begin{array}{c}\text { Generally, this program change behavior of teachers in } \\
\text { classroom. }\end{array}$ & 16 \\
\hline 16 & 3.18 & 192 & 16 & 3.72 & 211 & $\begin{array}{l}\text { In general, researcher teacher can build and strengthen } \\
\text { motivated action research among teachers. }\end{array}$ & 17 \\
\hline 10 & 3.26 & 187 & 17 & 3.62 & 213 & $\begin{array}{l}\text { In general, researcher teacher can build and strengthen } \\
\text { motivated action research among schools administrators. }\end{array}$ & 18 \\
\hline 15 & 3.10 & 191 & 8 & 3.82 & 211 & $\begin{array}{l}\text { Researcher Teacher program leads to decentralization in } \\
\text { the research and graduation of study from the monopoly } \\
\text { of elites. }\end{array}$ & 19 \\
\hline & 3.26 & & & 3.80 & & Total average & \\
\hline
\end{tabular}

According to mean scores of researcher teachers and administrators (3.80) and mean scores of non-researcher teachers and administrators (3.26) we can say both groups have higher than average believed that the program has been successful and have achievements to earn.

In order to determine the differences between two groups of researcher and non- researcher teachers and 
administrators about the achievements, $t$ test is used. For more accurate results, 19 questions are arranged in two categories. The first group contains questions that measured researcher teacher's program achievements in the field of developing research-oriented school environment and the second category is intended to examined increase knowledge, improve attitudes and behaviors of teachers and administrators. The results of these two questions are presented in Tables 2 and 3.

Table 2. Comparison of researcher and non-researcher teachers and administrators ideas about penetrations of researcher teacher programs in development of research-oriented atmosphere and space in school (using T-Test, Group Statistics)

\begin{tabular}{|c|c|c|c|c|c|c|c|c|c|c|c|c|c|c|c|}
\hline \multicolumn{16}{|l|}{$95 \%$} \\
\hline \multicolumn{2}{|c|}{$\begin{array}{l}\text { Confidenc } \\
\text { e Interval } \\
\text { of the } \\
\text { Difference }\end{array}$} & \multirow{2}{*}{$\begin{array}{l}\text { Std. } \\
\text { Error } \\
\text { Differ } \\
\text { ence }\end{array}$} & \multirow{2}{*}{$\begin{array}{l}\text { Mean } \\
\text { Differ } \\
\text { ence }\end{array}$} & \multirow{2}{*}{$\begin{array}{l}\text { Sig. } \\
\text { (2-tai } \\
\text { led) }\end{array}$} & \multirow{2}{*}{$\begin{array}{l}\text { Degr } \\
\text { ee of } \\
\text { free } \\
\text { dom }\end{array}$} & \multirow{2}{*}{$\begin{array}{l}\mathrm{t} \\
\text { calcul } \\
\text { ated }\end{array}$} & \multirow{2}{*}{$\begin{array}{l}\text { signifi } \\
\text { cant }\end{array}$} & \multirow{2}{*}{$\begin{array}{l}\mathrm{F} \\
\text { calcul } \\
\text { ated }\end{array}$} & \multirow{2}{*}{$\begin{array}{l}\text { Varia } \\
\text { nces }\end{array}$} & \multirow{2}{*}{$\begin{array}{l}\text { Std } \\
\text { Err } \\
\text { or } \\
\text { Me } \\
\text { an }\end{array}$} & \multirow[t]{2}{*}{$\begin{array}{l}\text { Std. } \\
\text { Devia } \\
\text { tion }\end{array}$} & \multirow{2}{*}{$\begin{array}{l}\text { Me } \\
\text { an } \\
\text { On } \\
\text { sca } \\
\text { le } \\
1-5\end{array}$} & \multirow{2}{*}{$\begin{array}{l}\text { num } \\
\text { ber }\end{array}$} & \multirow{2}{*}{$\begin{array}{l}\text { Grou } \\
\mathrm{p} \text { of } \\
\text { teach } \\
\text { ers } \\
\text { and } \\
\text { princi } \\
\text { pals }\end{array}$} & \multirow{2}{*}{$\begin{array}{l}\text { Achievem } \\
\text { ents }\end{array}$} \\
\hline $\begin{array}{l}\text { Lo } \\
\text { wer } \\
\text { lim } \\
\text { it } \\
\end{array}$ & $\begin{array}{l}\text { Lo } \\
\text { wer } \\
\text { lim } \\
\text { it }\end{array}$ & & & & & & & & & & & & & & \\
\hline $\begin{array}{l}-0.3 \\
8\end{array}$ & $\begin{array}{l}-0.7 \\
4\end{array}$ & 0.09 & -0.56 & 0.000 & 411 & -6.16 & 0.001 & 12.05 & $\begin{array}{l}\text { Equal } \\
\text { varia } \\
\text { nces } \\
\text { assu }\end{array}$ & $\begin{array}{l}0.0 \\
7\end{array}$ & 1.03 & $\begin{array}{l}3.2 \\
6\end{array}$ & 197 & $\begin{array}{l}\text { Non } \\
\text { Inqui } \\
\text { ring }\end{array}$ & $\begin{array}{l}\text { The } \\
\text { atmospher }\end{array}$ \\
\hline & & & & & & & & & med & & & & & & e and \\
\hline $\begin{array}{l}-0.3 \\
8\end{array}$ & $\begin{array}{l}-0.7 \\
4\end{array}$ & 0.09 & -0.56 & 0.000 & $\begin{array}{l}370 . \\
07\end{array}$ & -6.09 & & & $\begin{array}{l}\text { Equal } \\
\text { varia } \\
\text { nces } \\
\text { not } \\
\text { assu } \\
\text { med }\end{array}$ & $\begin{array}{l}0.0 \\
5\end{array}$ & 0.80 & $\begin{array}{l}3.8 \\
2\end{array}$ & 216 & $\begin{array}{l}\text { Inqui } \\
\text { ring }\end{array}$ & $\begin{array}{l}\text { space } \\
\text { research-o } \\
\text { riented } \\
\text { school }\end{array}$ \\
\hline
\end{tabular}

In general, $\mathrm{t}$ test reveals difference among mean scores significant with strong reliability $(\mathrm{sig}=0.000<0.01)$ which means the researcher teacher program has been successful in the field of research-oriented atmosphere and space in school from the perspective of researcher teachers and administrators 
Table 3. Comparison the viewpoints of researcher and non- researcher teachers and administrators about penetrations of researcher teacher program in increasing knowledge, improve attitudes and behaviors of teachers and managers (using T-Test, Group Statistics)

\begin{tabular}{|c|c|c|c|c|c|c|c|c|c|c|c|c|c|c|c|}
\hline \multicolumn{2}{|c|}{$\begin{array}{l}95 \% \\
\text { Confidence } \\
\text { Interval of } \\
\text { the } \\
\text { Difference }\end{array}$} & \multirow[t]{2}{*}{$\begin{array}{l}\text { Std. } \\
\text { Error } \\
\text { Differ } \\
\text { ence }\end{array}$} & \multirow[t]{2}{*}{$\begin{array}{l}\text { Mean } \\
\text { Differ } \\
\text { ence }\end{array}$} & \multirow[t]{2}{*}{$\begin{array}{l}\text { Sig. } \\
\text { (2-tai } \\
\text { led) }\end{array}$} & \multirow[t]{2}{*}{$\begin{array}{l}\text { Degr } \\
\text { ee of } \\
\text { freed } \\
\text { om }\end{array}$} & \multirow[t]{2}{*}{$\begin{array}{l}\mathrm{t} \\
\text { calcul } \\
\text { ated }\end{array}$} & \multirow[t]{2}{*}{$\begin{array}{l}\text { signifi } \\
\text { cant }\end{array}$} & \multirow[t]{2}{*}{$\begin{array}{l}\mathrm{F} \\
\text { calcul } \\
\text { ated }\end{array}$} & \multirow[t]{2}{*}{$\begin{array}{l}\text { varia } \\
\text { nces }\end{array}$} & \multirow[t]{2}{*}{$\begin{array}{l}\text { Std } \\
\text { Err } \\
\text { or } \\
\text { Me } \\
\text { an }\end{array}$} & \multirow[t]{2}{*}{$\begin{array}{l}\text { Std. } \\
\text { Devia } \\
\text { tion }\end{array}$} & \multirow{2}{*}{$\begin{array}{l}\text { Me } \\
\text { an } \\
\text { On } \\
\text { sca } \\
\text { le } \\
1-5\end{array}$} & \multirow[t]{2}{*}{$\begin{array}{l}\text { num } \\
\text { ber }\end{array}$} & \multirow{2}{*}{$\begin{array}{l}\text { Grou } \\
\mathrm{p} \text { of } \\
\text { teach } \\
\text { ers } \\
\text { and } \\
\text { princi } \\
\text { pals }\end{array}$} & \multirow[t]{2}{*}{$\begin{array}{l}\text { Achieve } \\
\text { ments }\end{array}$} \\
\hline & $\begin{array}{l}\text { Lo } \\
\text { wer }\end{array}$ & & & & & & & & & & & & & & \\
\hline $\begin{array}{l}-0.3 \\
2\end{array}$ & $\begin{array}{l}-0.7 \\
2\end{array}$ & 0.10 & -0.52 & 0.000 & 408 & -5.13 & 0.001 & 11.0 & $\begin{array}{l}\text { Equal } \\
\text { varia } \\
\text { nces } \\
\text { assu } \\
\text { med }\end{array}$ & $\begin{array}{l}0.0 \\
8\end{array}$ & 1.12 & $\begin{array}{l}3.2 \\
6\end{array}$ & 194 & $\begin{array}{l}\text { Non } \\
\text { Inquir } \\
\text { ing }\end{array}$ & $\begin{array}{l}\text { Increase } \\
\text { knowled } \\
\text { ge, } \\
\text { improve } \\
\text { attitudes }\end{array}$ \\
\hline $\begin{array}{l}-0.3 \\
2\end{array}$ & $\begin{array}{l}-0.7 \\
2\end{array}$ & 0.10 & -0.52 & 0.000 & 375 & -5.08 & & & $\begin{array}{l}\text { Equal } \\
\text { varia } \\
\text { nces } \\
\text { not } \\
\text { assu } \\
\text { med }\end{array}$ & $\begin{array}{l}0.0 \\
6\end{array}$ & 0.92 & $\begin{array}{l}3.7 \\
7\end{array}$ & 216 & $\begin{array}{l}\text { Inquir } \\
\text { ing }\end{array}$ & $\begin{array}{l}\text { and } \\
\text { behavior } \\
\mathrm{s} \quad \text { of } \\
\text { teachers } \\
\text { and } \\
\text { principal } \\
\mathrm{s}\end{array}$ \\
\hline
\end{tabular}

Generally, $\mathrm{t}$ test reveals meaningful difference among two average $(\mathrm{sig}=0.000<0.01$ ) with strong reliability which means from the perspective of teachers and administrators increase knowledge, improve attitudes and behaviors of teachers and administrators as the achievements of researcher teacher is higher than of non-researcher teachers and administrators.

The answer to the second question: Is there a significant difference between participations of two groups of researcher and non-researcher teachers and administrators in school activities in the context of implementing corresponding program?

To answer this question, special questions are included in the questionnaire that demonstrate the participation of researcher teachers and administrators in school activities in the field of implementation of program includes holding briefings, workshops and measure teachers Council. The answers of two groups of teachers and administrators to questions are presented in Table 4.

Table 4. Answers of two groups of teachers and administrators about the participation in school activities in the field of researcher teacher program

\begin{tabular}{|c|c|c|c|c|c|c|c|c|c|c|c|c|}
\hline \multicolumn{4}{|c|}{$\begin{array}{l}\text { Participation in the meetings of the } \\
\text { Council of teachers in improving } \\
\text { researcher teacher program }\end{array}$} & \multicolumn{4}{|c|}{$\begin{array}{l}\text { Participation in school workshops in } \\
\text { the field of action research }\end{array}$} & \multicolumn{4}{|c|}{$\begin{array}{l}\text { Participation school briefings about } \\
\text { researcher teacher }\end{array}$} & questions \\
\hline $\begin{array}{l}\text { Alway } \\
s\end{array}$ & $\begin{array}{l}\text { someti } \\
\text { mes }\end{array}$ & rarely & Never & $\begin{array}{l}\text { Alway } \\
\text { s }\end{array}$ & $\begin{array}{l}\text { someti } \\
\text { mes }\end{array}$ & rarely & Never & $\begin{array}{l}\text { Alway } \\
\text { s }\end{array}$ & $\begin{array}{l}\text { someti } \\
\text { mes }\end{array}$ & rarely & Never & Options \\
\hline $19.9 \%$ & $44.7 \%$ & $18.9 \%$ & $16.5 \%$ & $9.9 \%$ & $36.6 \%$ & $19.8 \%$ & $33.7 \%$ & $20.3 \%$ & $43.5 \%$ & $18.4 \%$ & $17.9 \%$ & $\begin{array}{ll}\text { Percent non } \\
\text { researcher } \\
\text { teachers and } \\
\text { principals }\end{array}$ \\
\hline $24.9 \%$ & $44.5 \%$ & $15.3 \%$ & $15.3 \%$ & $12.0 \%$ & $42.6 \%$ & $16.3 \%$ & $29.2 \%$ & $28.4 \%$ & $46.0 \%$ & $13.3 \%$ & $12.3 \%$ & $\begin{array}{l}\text { Percent Of } \\
\text { researcher } \\
\text { teachers and } \\
\text { administrators }\end{array}$ \\
\hline
\end{tabular}

To compare the participation of two groups of teachers and administrators in briefings meeting in school in the field of researcher teacher program, chi-square test is used. This test separate the difference levels of notification 
with sufficient confidence (at least at 90 percent confidence level, sig $=<0$. 1) (sig $=<0.10$ ). Hence, it can be stated that researcher teachers and administrators participate in the briefings meeting in schools.

In the case of educational workshops in school in the field of action research and council meetings of teachers, although participation rates of researcher teachers and administrators was more than non- researcher ones, chi-square test does not show a significant difference with sufficient confidence in both cases. (sig $>0.05)$, which mean no relationship exist between teachers and administrators participations in workshops and attendance at council of teachers meetings.

The answer to third question: Is there a significant difference between two groups of researcher and non-researcher teachers and administrators about the shortcomings and obstacles of the program?

To answer this question 27 items are included in the questionnaire in order that case studied samples express their opinion abide by selecting the appropriate option. The mean score responses and their ranks based on two groups of respondents are presented in Table 5 .

Table 5. The mean score responses and their ranks based on two groups of respondents

\begin{tabular}{|c|c|c|c|c|c|c|c|c|c|c|}
\hline \multicolumn{2}{|c|}{$\begin{array}{l}\text { Non researche } \\
\text { and principals }\end{array}$} & teachers & \multicolumn{3}{|c|}{$\begin{array}{l}\text { researcher Teachers and } \\
\text { administrators }\end{array}$} & \multirow{2}{*}{$\begin{array}{l}\text { Obstacles and shortcomings of researcher } \\
\text { teacher program }\end{array}$} & \multirow{2}{*}{ row } & \multirow{2}{*}{\multicolumn{2}{|c|}{$\begin{array}{l}\text { Classification } \\
\text { obstacles } \\
\text { shortcomings }\end{array}$}} & \multirow{2}{*}{$\begin{array}{r}\text { of } \\
\text { and }\end{array}$} \\
\hline rank & $\begin{array}{l}\text { mean } \\
\text { score }\end{array}$ & number & rank & $\begin{array}{l}\text { mean } \\
\text { score }\end{array}$ & number & & & & & \\
\hline 23 & 2.91 & 192 & 14 & 2.95 & 214 & $\begin{array}{l}\text { How can Limitations of teachers discipline } \\
\text { influence on preventing their participation in } \\
\text { the researcher teacher program? }\end{array}$ & 1 & & & \\
\hline 19 & 3.03 & 194 & 9 & 3.10 & 214 & $\begin{array}{l}\text { How can restrictions of teacher education } \\
\text { impact on inhibiting their participation in the } \\
\text { program? }\end{array}$ & 2 & & & \\
\hline 18 & 3.04 & 192 & 11 & 3.05 & 212 & $\begin{array}{l}\text { How can teachers work experience limitations } \\
\text { influence in inhibiting their participation in the } \\
\text { program? }\end{array}$ & 3 & & & \\
\hline 8 & 3.35 & 191 & 7 & 3.34 & 210 & $\begin{array}{l}\text { How can teachers gender restrictions impact } \\
\text { on preventing their participation in the } \\
\text { program? }\end{array}$ & 4 & & & \\
\hline 3 & 3.97 & 191 & 3 & 3.96 & 211 & $\begin{array}{l}\text { How can economic problems impact on } \\
\text { preventing their participation in the program? }\end{array}$ & 5 & $\begin{array}{l}\text { Related } \\
\text { person }\end{array}$ & & \\
\hline 1 & 4.26 & 191 & 1 & 4.30 & 213 & $\begin{array}{l}\text { How can Lack of time for study and research } \\
\text { in school impact on preventing their } \\
\text { participation in the program? }\end{array}$ & 6 & & & \\
\hline 2 & 4.06 & 193 & 2 & 4.17 & 213 & $\begin{array}{l}\text { How can lack of dominancy on preparation } \\
\text { reports related to action research impact on } \\
\text { teachers participations in the program? }\end{array}$ & 7 & & & \\
\hline 20 & 3.01 & 191 & 15 & 2.94 & 211 & $\begin{array}{l}\text { How much is school teachers dominate on the } \\
\text { action research methodology? }\end{array}$ & 8 & & & \\
\hline 4 & 3.78 & 192 & 5 & 3.62 & 213 & $\begin{array}{l}\text { What is the rate of Lack of motivation and } \\
\text { research spirit of teachers in the school to } \\
\text { participate in a researcher teacher program? }\end{array}$ & 9 & & & \\
\hline 10 & 3.29 & 191 & 8 & 3.27 & 211 & $\begin{array}{l}\text { How much school teachers being informed } \\
\text { about philosophy, concept and objectives of } \\
\text { the researcher teacher? }\end{array}$ & 10 & & & \\
\hline 25 & 2.59 & 187 & 25 & 2.41 & 210 & $\begin{array}{l}\text { How much cooperation of schools managers' } \\
\text { impact on the promotion of researcher teacher } \\
\text { program? }\end{array}$ & 11 & $\begin{array}{l}\text { Related } \\
\text { school }\end{array}$ & & the \\
\hline 21 & 2.98 & 192 & 21 & 2.64 & 211 & $\begin{array}{l}\text { How much the research substrate is provided } \\
\text { at the school? (Culture, research, manager } \\
\text { interests, colleague cooperation, etc.) }\end{array}$ & 12 & & & \\
\hline
\end{tabular}




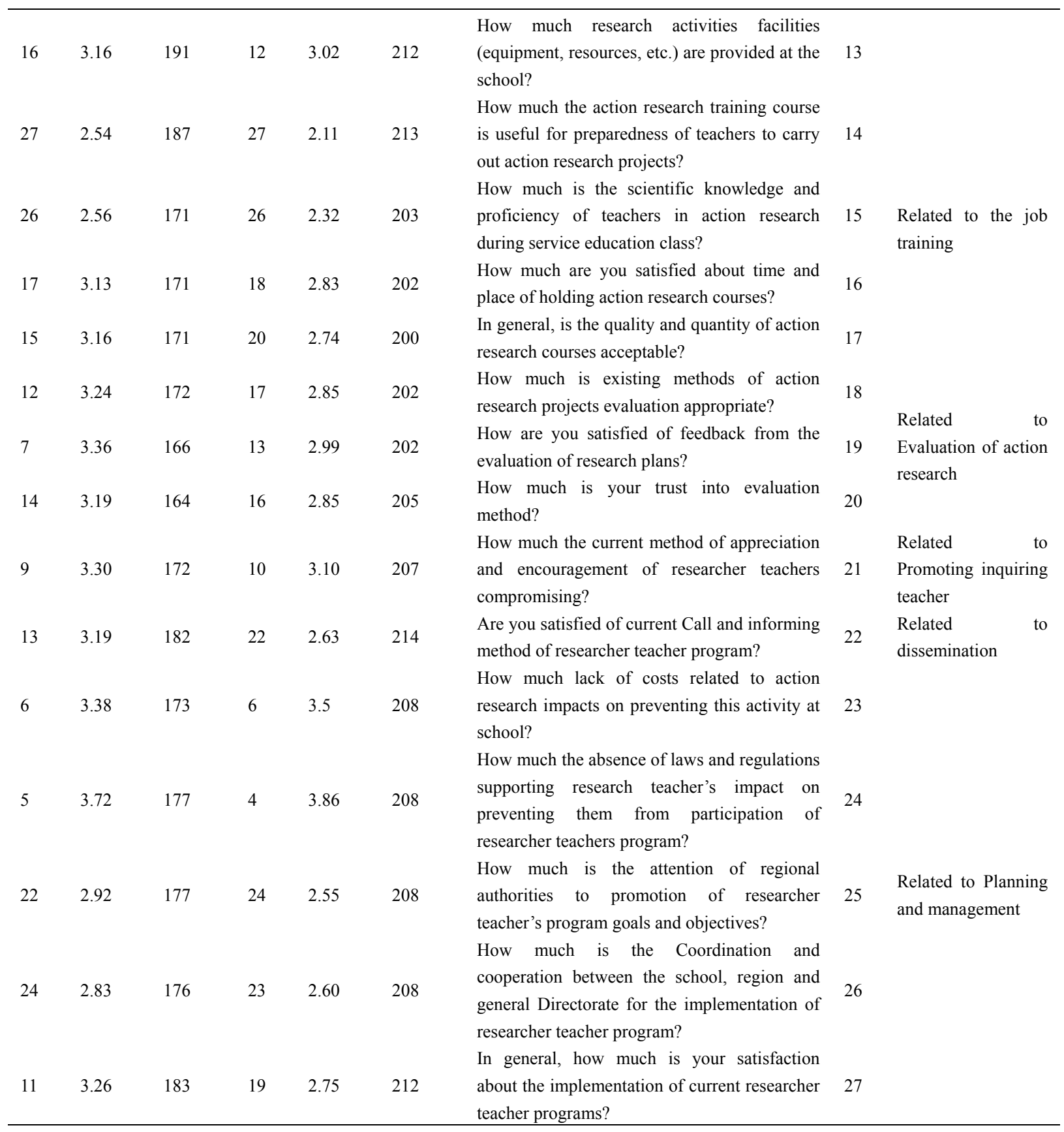

In order to determine the differences between two groups of researcher and non- researcher teachers and administrators about the obstacles and shortcomings of the program, t-test is used in which the results are presented in Table 6. 
Table 6. Comparison of researcher and non-researcher teachers and administrators viewpoints about the obstacles and shortcomings of researcher Teacher program (using T-Test, Group Statistics)

\begin{tabular}{|c|c|c|c|c|c|c|c|c|c|c|c|c|c|c|}
\hline \multicolumn{15}{|l|}{$95 \%$} \\
\hline \multicolumn{2}{|c|}{ Confidence } & \multirow{3}{*}{$\begin{array}{l}\text { Std. } \\
\text { Error } \\
\text { Differe } \\
\text { nce }\end{array}$} & \multirow{3}{*}{$\begin{array}{l}\text { Mean } \\
\text { Differe } \\
\text { nce }\end{array}$} & \multirow{3}{*}{$\begin{array}{l}\text { Sig. } \\
\text { (2-tail } \\
\text { ed) }\end{array}$} & \multirow{3}{*}{$\begin{array}{l}\text { Degr } \\
\text { ee of } \\
\text { freed } \\
\text { om }\end{array}$} & \multirow{3}{*}{$\begin{array}{l}\mathrm{t} \\
\text { calcul } \\
\text { ated }\end{array}$} & \multirow{3}{*}{$\begin{array}{l}\text { signifi } \\
\text { cant }\end{array}$} & \multirow{3}{*}{$\begin{array}{l}\mathrm{F} \\
\text { calcul } \\
\text { ated }\end{array}$} & \multirow{3}{*}{$\begin{array}{l}\text { varian } \\
\text { ces }\end{array}$} & \multirow{3}{*}{$\begin{array}{l}\text { Std } \\
\text { Err } \\
\text { or } \\
\text { Me } \\
\text { an }\end{array}$} & \multirow{3}{*}{$\begin{array}{l}\text { Std. } \\
\text { Deviat } \\
\text { ion }\end{array}$} & \multirow{3}{*}{$\begin{array}{l}\text { Me } \\
\text { an } \\
\text { On } \\
\text { scal } \\
\text { e } \\
1-5\end{array}$} & \multirow{3}{*}{$\begin{array}{l}\text { num } \\
\text { ber }\end{array}$} & \multirow{3}{*}{$\begin{array}{l}\text { Group of } \\
\text { teachers } \\
\text { and } \\
\text { principals }\end{array}$} \\
\hline $\begin{array}{l}\text { Interv } \\
\text { the } \\
\text { Diffe }\end{array}$ & ence & & & & & & & & & & & & & \\
\hline & $\begin{array}{l}\text { Lo } \\
\text { wer }\end{array}$ & & & & & & & & & & & & & \\
\hline 0.28 & 0.10 & 0.05 & 0.19 & 0.000 & 407 & 4.027 & 0.435 & 0.61 & $\begin{array}{l}\text { Equal } \\
\text { varian } \\
\text { ces } \\
\text { assum } \\
\text { ed }\end{array}$ & $\begin{array}{l}0.0 \\
3\end{array}$ & 0.49 & $\begin{array}{l}3.2 \\
4\end{array}$ & 195 & $\begin{array}{l}\text { Non-resea } \\
\text { rcher }\end{array}$ \\
\hline 0.28 & 0.10 & 0.05 & 0.19 & 0.000 & $\begin{array}{l}396.5 \\
8\end{array}$ & 4.014 & & & $\begin{array}{l}\text { Equal } \\
\text { varian } \\
\text { ces } \\
\text { not } \\
\text { assum } \\
\text { ed }\end{array}$ & $\begin{array}{l}0.0 \\
3\end{array}$ & 0.45 & $\begin{array}{l}3.0 \\
6\end{array}$ & 214 & researcher \\
\hline
\end{tabular}

Totally, t-test shows significant differences between averages with strong confidence $(\mathrm{sig}=0.000<0.01)$ which means non-researcher teachers believe obstacles shortcomings of this program is greater than what was assumed by researcher teachers.

\section{Conclusion}

This paper has investigated the researcher teacher program in three categories including quantitative and qualitative achievements, the level of activities executed in the field of researcher teacher by schools in partnership of teachers and administrators and obstacles and shortages in terms of researcher and non-researcher teachers and administrator's viewpoints. Particularly, about quantitative and qualitative achievements both sample groups state that researcher teacher led the research-oriented atmosphere and space in the school and impact on enhancement of knowledge, improve attitudes and behavior of school teachers and administrators in higher than average level.

However, due to the significant difference between the mean scores of two groups it can be concluded that achievements of researcher teacher program has been much more than for non-researcher teachers and administrators.

Meanwhile, about activities carried out about researcher teacher program by schools in accordance with teachers and administrators partnership results showed that although both groups have participated higher than average in briefings meeting, but according to the chi-square test results researcher teachers and administrators had participated more than non-researcher ones. The results indicate that about holding workshops both groups participations was less than average and about meetings of teachers Council both group participate higher than average. However, the participation of researcher teachers and administrators were more than non-researcher one, but chi-square test showed no significant difference.

About obstacles and shortcomings of research, findings showed that both groups accept significantly higher than the average of the shortages mentioned about researcher teacher program but

due to the significant difference observed in average score by using the $t$ test, non-researcher teachers and administrators have assessed obstacles and shortcomings of the program more than researcher teacher and administrators.

- Lack of study and research time at school (Rank 1)

- Not dominant in preparation of action research report (rank 2)

- Economic problems of teachers (Rank 3)

The next obstacles are either the same or compromised by one rank for each Group: 
- Lack of motivation and research spirit of teacher in the school to participate in researcher teacher program (rank 4 is attributed to non-researcher and rank 5 is attributed to researcher)

- The absence of laws and regulations supportive for researcher teacher participated in researcher teacher program (rank 4 is attributed to non-researcher and rank 5 is attributed to researcher)

- Lack of school fees for executing action research (rank 6 by both groups)

\section{Suggestions}

1) Researcher Teacher program must be revised so that by providing supportive laws and regulations for researcher teachers attracts more teachers to participate in this program.

2) Holding qualitative briefings meetings, workshops and teacher's council meetings in the field of researcher teachers program to enhance the motivation and ability of them to execute action research.

3) Necessary opportunities to study and carry out action research to be included in the teacher's routine schedules.

4) Sufficient mechanism must be provided for estimating the costs of executing action research to support the necessary financial resources at the disposal of teachers.

\section{References}

Ahanchian, M. R. (2007). Involvement in the production of organizational knowledge through action research. Educational Bulletin No. 25, Institute of Education Studies.

Amoozaadeh, H. (2005), identification of factors affecting expansion of researcher teacher program among elementary school teachers in Tehran, MA thesis, University of Shahid Beheshti.

Chaychi, P. (2005). Critique of researcher teacher's goals. Educational Bulletin, Issue 4. Institute of Education Studies

Chaychi, P. (2006). Assessment of realization of researcher teacher program and suggesting modifications recommendations. Institute of Education Studies.

Esfahani, S. N., Mohsen, T. A., Moghaddam, N. S., Reza, M., \& Mohammad, E. (2016). Independent tuning of stiffness and toughness of additively manufactured titanium-polymer composites: Simulation, fabrication, and experimental studies. Journal of Materials Processing Technology, 238, 22-29. https://doi.org/10.1016/j.jmatprotec.2016.06.035

Haqgoo, N. (2004). History of Action Research. Educational Research Bulletin No. 78. Institute of Education

Institute of Education, Tehran. (1996). Procedures of researcher teacher program.

Moghaddam, N. S. (2015). Toward Patient Specific Long Lasting Metallic Implants for Mandibular Segmental Defects (PhD diss., University of Toledo).

Moghaddam, N. S., Skoracki, R., M. Miller, M. Elahinia, \& Dean, D. (2014). Enhancement of Bone Implants by Substituting Nitinol for Titanium (Ti-6Al-4V): A Modeling Comparison. In ASME 2014 Conference on Smart Materials, Adaptive Structures and Intelligent Systems, pp. V001T03A031-V001T03A031. American Society of Mechanical Engineers.

Moghaddam, N. S., Skoracki, R., M. Miller, M. Elahinia, \& Dean, D. (2016). Three Dimensional Printing of Stiffness-tuned, Nitinol Skeletal Fixation Hardware with an Example of Mandibular Segmental Defect Repair. Procedia CIRP, 49, 45-50. https://doi.org/10.1016/j.procir.2015.07.027

Nami, S. H. (2014). Study of researcher teacher program and provide a model for its development and generalization. Study Education Research Institute, Tehran

Qasemi-Puya. A. (2003). Handbook of researcher teacher. Publisher golden scheme, Tehran.

\section{Copyrights}

Copyright for this article is retained by the author(s), with first publication rights granted to the journal.

This is an open-access article distributed under the terms and conditions of the Creative Commons Attribution license (http://creativecommons.org/licenses/by/4.0/). 